\title{
Development of RP-HPLC method for the estimation of Rasagiline mesylate in bulk and tablet dosage forms
}

\author{
*Napa Delhi Raj', Abburu Rukmangada Rao', Chusena Narasimharaju Bhimanadhuni² \\ ${ }^{1}$ Nimra college of Pharmacy, Nimra nagar, Jupudi-521456, Vijayawada, Krishna (Dt), Andhra Pradesh, India \\ 2Department of Pharmaceutical Analysis, Annabattuni Satya Narayana Pharmacy College, Burripalem Road, Tenali- \\ 522201, Guntur (Dt), Andhra Pradesh, India
}

\begin{abstract}
A simple RP-HPLC method for the determination of Rasagiline Mesylate in bulk and tablet dosage form was developed. Numerous HPLC conditions were tested for determination of rasagiline. The best result was achieved by using Purosphere star RP-18, $(150 \times 4.6 \mathrm{~mm}), 5 \mu \mathrm{m}$ column and a mobile phase consisting of Potassium Orthophosphate: Acetonitrile $(60: 40 \mathrm{v} / \mathrm{v})$ adjusted to $\mathrm{pH} 7.0( \pm 0.05)$ with Ammonia solution, a flow rate of $1.5 \mathrm{ml} / \mathrm{min}$ with ultraviolet detection at $210 \mathrm{~nm}$. The correlation coefficients for calibration curves within the detection range of $5-30 \mu \mathrm{g} / \mathrm{ml}$ were 0.9993. The within and between-day precision was determined for both retention time and peak area. The retention time of rasagiline is 6.0 minutes.
\end{abstract}

Key Words: Rasagiline, Purosphere star RP-18, Tablets, Estimation, RP-HPLC,Validation, Method development.

\section{INTRODUCTION}

Rasagiline mesylate is a chemical inhibitor of the enzyme monoamine oxidase type-B which has a major role in the inactivation of biogenic and dietderived amines in the central nervous system. Rasagiline is a propargylamine-based drug indicated for the treatment of idiopathic Parkinson's disease. It is designated chemically as, 1H-Inden-1amine, 2, 3-dihydro-N-2-propynyl-, (1R)-, methanesulfonate. The empirical formula of rasagiline mesylate is $\left(\mathrm{C}_{12} \mathrm{H}_{13} \mathrm{~N}\right) \mathrm{CH}_{4} \mathrm{SO}_{3}$ and its molecular weight is 267.34. Rasagiline is freely soluble in water and ethanol and sparingly soluble in isopropyl alcohol. It is a chiral compound with one asymmetric carbon atom in a five member ring with an absolute with R-configuration which is produced as single enantiomers (Chen et al., 2007). Literature survey reveals that only a few methods based on RP-HPLC method was developed and validated for the determination of rasagiline mesylate in pharmaceutical dosage forms (Vijayalakshmi et al., 2010).

\footnotetext{
*Corresponding Author:

Napa Delhi Raj, Associate Professor

Department of Pharmaceutical analysis

Nimra college of pharmacy, Nimra nagar, Jupudi- 521456

Vijayawada, Krishna (Dt), Andhra Pradesh, India.

E-mail: pharmaraj1981@gmail.com

Contact No.: +91 8985351361
}

Stability indicating RP-LC method for determination of rasagiline mesylate in bulk and pharmaceutical dosage forms (Kumar et al., 2010). LC-mass Spectrometry method for the determination of rasagiline mesylate in human plasma (Song et al., 2007). LC-MS-MS method for the study of metabolism, excretion and pharmacokinetics of rasagiline in healthy human subjects (Ma et al., 2003). Validated and stability indicating dissolution test with reverse phase-hplc analysis for rasagiline mesylate in tablet dosage form (Poongoothai et al., 2011). Spectrophotometric method in ultraviolet region has been developed for the determination of Rasagiline in bulk and in pharmaceutical formulations (Rama et al., 2010). Reverse phase liquid chromatography method for the quantification of rasagiline mesylate in biodegradable PLGA microspheres. (Fernandez et al., 2008). The present investigation by the author describes a rapid, accurate and precise RP-HPLC method for the determination of rasagiline mesylate from bulk sample and pharmaceutical dosage form. Since this drug is being marketed in domestic and international market. The method was validated as per ICH guidelines. 
Table 1: Analysis of pharmaceutical formulation.

\begin{tabular}{lccc}
\hline Pharmaceutical formulation & Labelled amount (mg) & $\begin{array}{c}\text { Assay found by proposed } \\
\text { method (\%) (mg) }\end{array}$ & $\begin{array}{c}\text { Recovery by proposed } \\
\text { method (\%) }\end{array}$ \\
\hline Rasagiline tablet & 0.5 & $98 \pm 0.4$ & $99.85 \pm 0.41$ \\
Rasagiline tablet & 1.0 & $98 \pm 0.2$ & $99.95 \pm 0.54$ \\
\hline aAverage \pm SD $(\mathrm{n}=6)$ & &
\end{tabular}

\section{EXPERIMENTAL}

The waters HPLC equipped with 2487 pump and UV-detector was used. The output signal was monitored and integrated using Waters Empower 2 software. The reference standard of Rasagiline was supplied by M/s Orchid Pharmaceuticals, Chennai, India and Rasagiline Tablets (Azilent 1mg) was purchased from local drug store. HPLC Acetonitrile was purchased from Merck (Mumbai, India) and potassium dihydrogen orthophosphate and ammonia solution was obtained from S.D Fine (Mumbai, India). All chemicals were of analytical grade. The column used in the development for determination is Purosphere star RP-18, (150×4.6mm), $5 \mu \mathrm{m}$ column.

\section{Mobile phase}

Accurately $1.36 \mathrm{~g}$ of potassium orthophosphate was weighed and dissolved in $1000 \mathrm{ml}$ of milli-Q water. The $\mathrm{pH}$ of the above solution was adjusted to $7.0 \pm$ 0.05 with Ammonia solution. Phosphate buffer solution and Acetonitrile was mixed in the ratio of 600:400 v/v, filtered through solution through $0.45 \mu \mathrm{m}$ nylon membrane filter and degassed for about $10 \mathrm{~min}$. The mobile phase was used as diluents. The mobile phase was filtered through $0.05 \mu$ membrane filter and sonicated by using Power Sonicator, model no. 405, Hwashin Technology, Korea before use. The detector wavelength was set at $210 \mathrm{~nm}$. A flow rate of $1.5 \mathrm{ml} / \mathrm{min}$ was used for the determination of rasagiline. The samples and standards were dissolved in the mobile phase and $20 \mu \mathrm{l}$ samples were injected into the HPLC system at the column and sample temperature of $30^{\circ} \mathrm{C}$.

\section{Preparation of Standard and Sample solutions}

Accurately $39.0 \mathrm{mg}$ of Rasagiline mesylate was weighed and transferred about into a $100 \mathrm{ml}$ volumetric flask and added about $60 \mathrm{ml}$ of diluent, sonicated to dissolve, maintained the solution to room temperature and diluted to the volume with diluent. $2.0 \mathrm{ml}$ of the above solution was transferred into a $50 \mathrm{ml}$ volumetric flask and diluted to the volume with diluent. The Solution was filtered through $0.45 \mu \mathrm{m}$ nylon membrane filter.

Ten tablets of rasagiline were weighed and powdered uniformly in a mortar. An accurately weighed portion powder equivalent to $5 \mathrm{mg}$ of rasagiline was transferred into a $200 \mathrm{ml}$ volumetric flask. $120 \mathrm{ml}$ of diluent was added, stirred for 10minutes on Orbital shaker and Sonicated for 20minutes with occasional stirring, maintained the solution to room temperature and diluted to the volume with diluent, filtered the solution through $0.45 \mu \mathrm{m}$ filter. Transferred $10 \mathrm{ml}$ of the above filtered solution into a $25 \mathrm{ml}$ volumetric flask \& dilute to the volume with diluent. The solution was filtered through $0.45 \mu \mathrm{m}$ nylon membrane filter.

\section{RESULTS AND DISCUSSION}

The present study was aimed at developing a sensitive precise and accurate HPLC method for the analysis of rasagiline in tablets. In order to achieve optimum separation of the component peaks, mixtures of buffer with Acetonitrile in different combinations were tested as mobile phase on a Purosphere Star, RP-18, (150 x $4.6 \mathrm{~mm}), 5 \mu \mathrm{m}$ column using with mobile phase of Potassium Orthophosphate: Acetonitrile (60:40) adjusted to $\mathrm{pH} 7.0 \pm 0.05$ with Ammonia solution that good for the determination of rasagiline in tablets. The retention time of the compound was found to be 6 min (Fig.1). The main

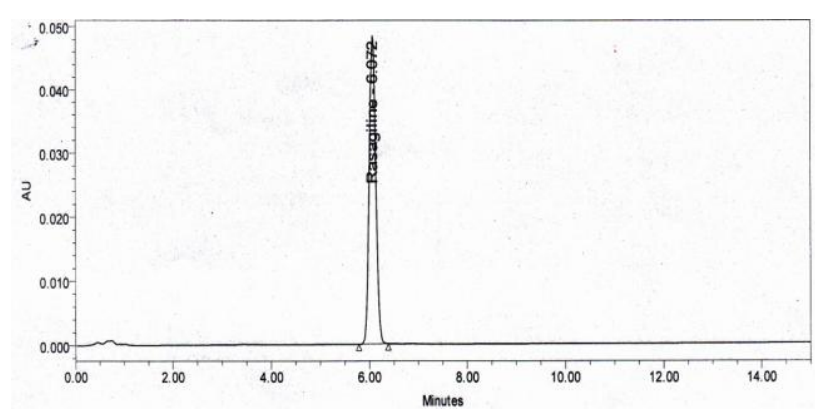

Figure 1: Chromatogram of Rasagiline. 
Table 2: Stability.

\begin{tabular}{llll}
\hline Experiment & $\begin{array}{l}\text { Percentage } \\
\text { degradation }\end{array}$ & $\begin{array}{l}\text { Purity } \\
\text { angle }\end{array}$ & $\begin{array}{l}\text { Purity } \\
\text { threshold }\end{array}$ \\
\hline $\begin{array}{l}\text { Photolytic } \\
\text { (2-day in Sun Light) }\end{array}$ & 3.71 & 0.120 & 1.349 \\
$\begin{array}{l}\text { Thermal } \\
\left(2-\text { day in } 110^{\circ} \mathrm{C}\right)\end{array}$ & 38.23 & 0.145 & 1.158 \\
$\begin{array}{l}\text { Alkali Deg } \\
(2-\mathrm{N} \mathrm{NaOH} \mathrm{1ml)}\end{array}$ & 21.48 & 0.890 & 2.335 \\
$\begin{array}{l}\text { Acid Deg } \\
(2-\mathrm{N} \mathrm{HCL} \mathrm{1ml)}\end{array}$ & 45.19 & 0.152 & 1.180 \\
$\mathrm{H}_{2} \mathrm{O}_{2} 50 \% \mathrm{w} / \mathrm{w}(1 \mathrm{ml})$ & 29.19 & 0.140 & 1.136 \\
\hline
\end{tabular}

advantage of this method is that it is simpler to carry out with regard to the preparation of samples and conditions used and thus it is less time consuming and less costly with the use of Purosphere Star, RP$18,(150 \times 4.6 \mathrm{~mm}), 5 \mu \mathrm{m}$ column.

To validate the RP-HPLC method, a series of tests were made using the most promising conditions. A calibration curve was made and concentration examined within the detection range of $5-30 \mu \mathrm{g} / \mathrm{ml}$ for rasagiline the correlation coefficient was found to be 0.9993 . The within-day, precision (expressed as the relative standard deviation (R.S.D)) for area under the curve (AUC) and retention times was determined for rasagiline for repeated analysis $(n=6)$ was found to be 0.17 and 0.79 respectively. Average within-day R.S.D values for between-day precision obtained for AUC were $0.41 \%$. The assay values obtained by proposed method and recovery experiment values obtained were performed by adding a fixed amount of drug to preanalyzed formulation summarized in Table 1 . The stability of sample was checked by forced degradation in different conditions and percentage of degradation was calculated. The peak purity of the analyte was passed in all conditions (purity angle should be less than the threshold value). The values in Table 2 indicate that the any other impurity is not merging with the main peak. The analyte solution was stable up to $14 \mathrm{hrs}$. The reliability of the method was determined by made small deliberate variations in method parameters and the RSD values in Table 3, an indication of its reliability on normal usage.

\section{CONCLUSION}

A method was developed for the determination for rasagiline in tablets which is simple, quick, reliable,
Table 3: Robustness.

\begin{tabular}{lll}
\hline S1. & Condition & \%RSD \\
No. & \\
\hline 1 & Flow $(+10 \%)$ & 0.20 \\
2 & Flow $(-10 \%)$ & 0.09 \\
3 & Temperature $\left(35^{\circ} \mathrm{C}\right)$ & 0.38 \\
4 & Organic $(+2 \% \mathrm{Abs})$ & 0.57 \\
5 & Organic $(-2 \% \mathrm{Abs})$ & 0.13 \\
6 & Wavelength $(+5 \mathrm{~nm})$ & 0.16 \\
7 & Wavelength $(-5 \mathrm{~nm})$ & 0.16 \\
8 & pH of the buffer $(+0.2)$ & 0.32 \\
9 & Robustness $-\mathrm{pH}$ of the buffer $(-0.2)$ & 0.55 \\
\hline
\end{tabular}

inexpensive and simple. The results indicate that the described method can be used for quantitative analysis of the compound.

\section{ACKNOWLEDGEMENT}

The authors are thankful to Principal, Dr. S. Duraivel, Nimra College of Pharmacy, Vijayawada, Andhra Pradesh for encouragement and providing laboratory facilities to carry out this research work.

\section{REFERENCES}

Chen, J.J., Swope, D.M. and Dashtipour, K. (2007) Comprehensive review of rasagiline, a second-generation monoamine oxidase inhibitor, for the treatment of Parkinson's Disease, Clinical Therapeutics .2007, vol. 29, no. 9, 1825-1849. [DOI]

Fernandez M., Barcia E., Negro S. (2009) Development and validation of a reverse phase liquid chromatography method for the quantification of rasagiline mesylate in biodegradable PLGA microspheres. J Pharm Biomed Anal., 49(5), 1185-1191. [DOI]

Kumar NR, Rao NG. and Naidu PY (2010) Stability indicating RP-LC method for determination of rasagiline mesylate in bulk and pharmaceutical dosage forms, International Journal of Applied Biology and Pharmaceutical Technology, vol. 1,no. 2,247-259.

Ma, J., Chen, X., Duan, X., Deng, P., Wang, H., Zhong, D. (2008) Validated LC-MS/MS method for quantitative determination of rasagiline in human plasma and its application to a pharmacokinetic study. J Chromatogr B, 873, 203- 208.

Rama, B., Preeti, K. (2010) UV Spectrophotometric method for the determination of rasagiline mesylate in bulk and pharmaceutical formulations,"International Journal of Pharmaceutical Sciences Review and Research, vol. 5, no. 1, pp. 5-7.

Song, M., Wang, L., Zhao, H., Hang T.J., Wen, AD, Yang L, Jia L. (2008) Rapid and sensitive liquid chromatography-tandem mass spectrometry: Assay development validation and application to a human pharmacokinetic study. J Chromatogr B, 875, 515-521.

Sundaramurthy Poongothai, Varadarajan Balaji, Rajasekhar Reddy, Raju Ilavarasan (2011) International Journal of Pharmaceutical Sciences Review and Research.2011, Volume 10, Issue 2, 18-23.

Vijayalakshmi, M., Seshagiri Rao, J.V.L.N. and A. Lakshmana Rao (2010) Development and validation of RP-HPLC method for the estimation of rasagiline tablet dosage forms, Rasayan Journal of Chemistry, vol. 3, no. 4, pp. 621-624. 